\title{
Pendidikan Kristen bagi Usia Lanjut di Gereja
}

\author{
Nancy F.L. Tobing \\ Sekolah Tinggi Teologi Sriwijaya \\ nancytobing0@gmail.com
}

\begin{abstract}
Christian education for the elderly is a teaching task that requires special attention. Because they are present among younger family members with various life problems. The church as a place for implementing Christian education requires educators who understand every struggle of the elderly and are able to contribute to the maturity of the faith of the elderly. This paper describes Christian education for the elderly in the church that can contribute to the congregation in carrying out their role in educating the elderly. The author uses a descriptive method based on the author's experiences and observations with the elderly in the Church. With this method, the writer analyzes to formulate the conception of Christian education learning for older adults. Then the author describes the strategies, principles and practices of Christian education for the elderly. Thus this paper can be useful for readers and educators to carry out the task of Christian education for the elderly in the Church.
\end{abstract}

Key word: elderly, Christian Education, church, strategy, principe and practice

\begin{abstract}
Abstrak: Pendidikan Kristen bagi lanjut usia adalah tugas pengajaran yang membutuhkan perhatian khusus. Karena mereka hadir di antara anggota keluarga yang usianya lebih muda dengan persoalan kehidupan yang beragam. Gereja sebagai wadah pelaksanaan pendidikan Kristen membutuhkan pendidik yang memahami setiap pergumulan lansia dan mampu berkontribusi untuk mendewasakan iman lansia. Makalah ini mendeskripsikan tentang pendidikan Kristen bagi lansia di dalam gereja yang dapat berkontribusi bagi warga jemaat dalam menjalankan peran mereka untuk membelajarkan lansia. Penulis menggunakan metode deskripsi yang didasarkan pada pengalaman dan pengamatan penulis bersama para lansia di Gereja. Dengan metode ini, penulis menganalisis untuk merumuskan konsepsi pembelajaran pendidikan Kristen untuk orang dewasa yang lebih tua. Kemudian penulis memaparkan tentang strategi, prinsip dan praktik pendidikan Kristen untuk lanjut usia. Demikianlah makalah ini dapat bermanfaat bagi para pembaca dan para pendidik untuk melaksanakan tugas pendidikan Kristen bagi para lanjut usia di Gereja.
\end{abstract}

Kata kunci: lansia, pendidikan kristen, gereja, strategi, prinsip dan praktik

Article History

\begin{tabular}{|l|l|l}
\hline Submitted: 2 Desember 2021 & Revised: 3 Frebruari 2022 & Accepted: 4 Februari 2022 \\
\hline
\end{tabular}

\section{PENDAHULUAN}

Pemahaman umum tentang manusia usia lanjut adalah seseorang, baik pria maupun perempuan, yang mengalami perubahan biologis, fisik, sikap, mental dan rohani. Indonesia menggolongkan usia lanjut adalah antara 55-60 tahun ke atas (Yasmin, 2021). Pemahaman ini sejalan dengan pandangan Elisabeth Hurlock, dalam bukunya Psikologi Perkembangan, yang membagi tahap perkembangan manusia dewasa dalam tiga tahapan, yakni: pertama, usia 18-40 tahun sebagai dewasa awal atau dewasa dini. Kedua, dewasa menengah atau dewasa madya adalah 40-60 tahun. Ketiga, dewasa akhir adalah 60 tahun ke atas (Hurlock, 2004). 
Penentuan batas usia lanjut tersebut, tentu diselidiki berdasarkan beberapa aspek yang memengaruhi manusia memasuki masa menua. Mengutip penjelasan Hanna Santoso dan Andar Ismail, dalam bukunya Memahami Krisis Lanjut Usia, menjabarkkan beberapa teori dasar penyebab manusia menjadi tua, demikian:

(A) teori Pakai-Rusak: tubuh dan sel-selnya banyak rusak karena banyak dipakai... (B) teori Jam Genetik atau Genetic Clock: proses penuaan telah terpogram secara genetik pada unsure terkecil di dalam inti sel. Setiap mahluk hidup seakan-akan memiliki "jam genetik" yang berjalan terus sampai masanya habis dan meninggal... (C) teori Neuro-Endokrin: proses menua berkaitan dengan kadar hormone di dalam tubuh. Hormon tubuh ini diatur oleh sistem jaringan biokimiawi yang kompleks dan rumit... (D) teori Immunologis: sistem kekebalan tubuh memberikan perlindungan terhadap serangan penyakit. Proses menua akan menurunkan fungsi sistem kekebalan ini, ... penurunan kadar immunoglobulin,... fungsi limfosit,... dan lain-lain... (E) teori Radikal Bebas: terjadinya proses menua pada tingkat seluler berdasarkan timbulnya kerusakan jaringan yang disebabkan oleh radikal bebas... (F) teori MelekatMemilin atau Cross-Linking: bertambah tua, protein manusia atau DNA dn molekul lainnya akan saling melekat dan memilin... (F) teori Telomerase: setiap kali sel tubuh membelah, telomer akan memendek. Bila ujung telomer sudah terlalu pendek, maka kemampuan sel untuk membelah akan dan berkurang, sampai akhirnya sel tidak dapat membelah diri lagi dan akhirnya mati (Santoso \& Ismail, 2016).

Teori-teori di atas menjelaskan bahwa perubahan-perubahan pada masa menua merupakan tahap lanjut dari suatu proses kehidupan yang ditandai dengan menurunnya kemampuan fisik, psikologis, sosiologis, dan spiritual manusia. Berdasarkan kemampuan fisik, usia lanjut mengalami perubahan yang cenderung menurun dalam segi sensitifitas, seperti kemampuan penglihatan, pendengaran, penciuman, perasa dan perabaan. Selain itu, perubahan fisik terlihat pada daerah kepala, tubuh, dan persendian, antara lain: kulit berkerut dan kering, mata kelihatan pudar, rambut menjadi putih, pada kulit wajah terdapat noda-noda coklat sebagai tanda penuaan sel, dsb.

Perubahan secara psikologis meliputi tingkah laku yang bersifat "kekanakkanakan," egosentris, gampang tersinggung, mempertahankan diri atas pengalaman dan pendapatnya sendiri, dan sebagainya. Hal ini, tentu berdampak pada pengakuan 
dan penerimaan diri sebagai pribadi yang memasuki dan sedang menjalani usia lanjut. ${ }^{1}$ Selanjutnya, kemampuan sosiologis untuk usia lanjut terlihat pada kebanggaan diri atas pengalaman pribadi yang lebih mapan. Mereka yang memasuki masa lansia lebih menonjolkan segala prestasi masa lalu yang diperlihatkan pada semangat bercerita kepada anak, menantu, cucu, dan orang-orang sekitarnya.

Perubahan spiritual yang tampak pada lansia adalah kecenderungan mereka untuk lebih dekat berhubungan dengan Tuhan yang diperlihatkan melalui kehadiran dan aktifitas ibadah minggu, doa pribadi, serta kegiatan rohani lainnya (seperti: aktif persekutuan lansia, paduan suara, dsb). Hal ini mereka lakukan sebagai upaya untuk merenungkan diri dengan segala masa lalunya, seraya berharap pengampunan dari Tuhan, sebelum ajal menghampirinya. Persiapan untuk menghadapi kematian ini mereka lakukan melalui beragam kesibukan di dalam dan sekitar komunitas gereja. Aktifitas kerohanian lansia merupakan usaha mereka untuk memenuhi kebutuhan dan pengakuan bahwa mereka mampu berbuat sesuatu.

Kemudian, perubahan fungsi mental dan fungsi kognitif yang paling jelas dialami oleh lansia adalah kemunduran daya ingat (Santoso \& Ismail, 2016). Penyebabnya adalah proses berpikir yang menjadi lamban, kurang dapat menggunakan strategi daya ingat yang tepat, kesulitan memusatkan perhatian, mudah teralih pada hal yang tidak penting, perlu lebih banyak waktu untuk belajar hal baru, dan memerlukan lebih banyak isyarat bantuan untuk mengingat-ingat kembali peristiwa dulu. Dengan kata lain, setiap manusia mengalami pertambahan usia. Pertambahan usia tersebut berdampak juga pada penurunan terhadap kecepatan belajar, kecepatan di dalam memproses informasi baru, dan kecepatan bereaksi terhadap rangsangan sekitarnya.

Para lansia di dalam gereja merupakan warga jemaat yang cenderung kurang mendapat perhatian khusus (GKPI, 2019). Hal ini disebabkan oleh pemahaman umum bahwa mereka aktif beribadah di dalam gereja, bertujuan sebagai persiapan untuk menghadapi kematian. Selain itu, penambahan usia dan menjadi tua merupakan masa bermasalah. Karena setiap perubahan yang dialami lansia memperlihatkan kekurangproduktifitas dan ketidak-mampuan mereka, sehingga perasaan menyesal, takut dan kuatir lebih besar memengaruhi cara berpikir dan bertindaknya. Mereka dipandang sebagai pribadi yang tidak memiliki kemampuan sebagaimana orang dewasa umumnya (UKDW, n.d.).

\footnotetext{
${ }^{1}$ Selanjutnya, penulis menuliskan lansia untuk menyebut usia lanjut.
} 
Berdasarkan uraian di atas, tujuan penelitian ini adalah untuk mendeskripsikan dan merumuskan kembali hal-hal pokok yang perlu dikembangkan dalam pelayanan gereja bagi para lansia. Pendidikan Kristen merupakan sarana pembentukan umat Tuhan untuk menjadi orang-orang terdidik berdasarkan Alkitab. Salah satu konteks pendidikan Kristen yang penulis uraikan pada artikel ini adalah gereja (Bandung, n.d.). Dalam hal ini, gereja didefinisikan sebagai persekutuan orang-orang percaya yang dipanggil keluar untuk menjadi saksi Kristus. Penggunaan kata persekutuan orangorang percaya berarti mencakup segala usia, tanpa pengecualian.

\section{METODE}

Penulisan artikel ini menggunakan metode kualitatif dengan pendekatan deskriptif-analisis. Pendekatan deskriptif sebagai upaya penulis untuk membuat gambaran mengenai situasi atau kejadian tentang hubungan, kegiatan, sikap, pandangan, dan pengaruh dari suatu fenomena (Nazir, 2003) yang berhubungan dengan lansia Kristen. Penulis menganalisisnya untuk merumuskan dan menentukan konsepsi belajar bagi lansia, strategi pendidikan Kristen lansia di gereja, dan PAK lansia yang mentransformasi.

\section{HASIL DAN PEMBAHASAN}

\section{Konsepsi Belajar Pendidikan Kristen Bagi Lansia}

Pada dasarnya, para lansia adalah orang dewasa lanjut yang dipakai oleh Tuhan untuk menjadi teladan hidup terhadap sejarah pertumbuhan dan perkembangan dunia. Dalam hal ini, tentu berhubungan dengan pergumulan dan tantangan yang perlu diketahui dan dipelajari oleh generasi muda. Alkitab menunjukkan bahwa orang berusia lanjut diberi peran dan diikutsertakan dalam komunitas sebagai narasumber. Contoh: Musa, dipanggil oleh Tuhan untuk memimpin Israel ketika ia berusia lanjut. Kepemimpinannya merupakan suatu gambaran bahwa Musa mendapat peran yang signifikan bagi Israel dalam memahami rencana Allah atas bangsa tersebut (Pardomuan, 2017).

Usia lanjut merupakan masa yang akan dialami oleh siapapun di dunia ini. Mereka yang sedang memasuki masa lansia, tentu keberadaannya nyata di lingkungan keluarga, gereja dan masyarakat. Ketiga lingkungan tersebut memberi pandangan dan sikap beragam dalam memperlakukan lansia. Misalnya, keluarga yang memiliki orang tua lansia, kerapkali terhisab dalam budaya tertentu untuk bersikap kepada mereka. 
Setahun yang lalu, ketika penulis diundang untuk menyampaikan renungan firman di tengah-tengah kelompok lansia pada salah satu rumah jompo di kota Palembang, penulis menyaksikan bahwa kebanyakan mereka dipandang oleh keluarganya sebagai 'beban,'² baik sosial, fisik dan psikologis. Anak mereka rela membayar mahal asal orang tua lansia bisa tinggal dan dirawat khusus oleh panti jompo tersebut. Mengutip pernyataan B.S. Sidjabat, menuliskan bahwa "pengalaman orang berusia lanjut...diwarnai oleh perasaan "malang" dan sia-sia serta ... berbagai pemerosotan, sesuai dengan perkataan Salomo dalam Pengk.12:1, "Ingatlah akan Penciptamu ..., sebelum tiba hari-hari yang malang dan mendekat tahun-tahun yang kaukatakan: Tak ada kesenangan bagiku di dalamnya!" (Sidjabat, 2014).

Kemudian, gereja adalah sarana yang dipakai Tuhan Allah untuk mempersiapkan orang dewasa agar peduli dan terdidik secara terampil dan dinamis dalam menghadapi warga jemaat lansia. Sejalan dengan tujuan pendidikan sebagaimana tertulis dalam Efesus 4:15 “...bertumbuh di dalam segala hal ke arah Dia..." Pertumbuhan ini mengarah pada kedewasaan kepribadian dan kedewasaan iman pendidik. Kedewasaan itu merupakan sesuatu yang terus menerus berkembang dan mengalami proses yang cukup panjang. Tentu saja, pernyataan ini tidak menutup kemungkinan bahwa lansia adalah pendidik yang dididik untuk terus berkembang hingga mereka kembali kepada Tuhan yang menciptanya.

Mengutip definisi PAK orang dewasa yang dicatat oleh Andar Ismail dalam pertemuan komisi PAK PGI, demikian: "PAK Orang Dewasa ialah usaha sengadja dari geredja di bawah pimpinan Roh Kudus untuk membuka kesempatan beladjar buat orang dewasa sehingga mereka dapat melajani Tuhan sesuai dengan bakat dan minat pribadi, kebutuhan keluarga, geredja, masjarakat umum dan dunia alam sekitarnya" (Poerwowidagdo, 2002).

Konsepsi belajar pendidikan Kristen bagi lansia di gereja, sejalan dengan definisi PAK di atas, adalah membina warga jemaat lansia untuk dibangun dan dipelihara mental dan rohani mereka, khususnya kemampuan untuk tetap semangat melayani Tuhan dalam beragam cara yang mereka minati dan senangi. Gereja merupakan sarana tepat terlaksananya pendidikan Kristen. Gereja menjadi wadah saling belajar dan mengajar yang menopang mereka. Topangan ini dimaksudkan agar warga jemaat lansia dapat menghargai masa tua mereka melalui perbuatan dan karya sebagai usaha untuk memaknai hidup yang Tuhan karunia.

\footnotetext{
${ }^{2}$ Mayoritas orang tua lansia tersebut telah tinggal di rumah jompo sekitar 5 tahun lebih, dan jarang dikunjungi oleh keluarganya. Rumah jompo ini disebut dengan Podomoro.
} 
Secara jelas, penulis mengutip lima kebutuhan yang dikategorikan sebagai kebutuhan penting dan mendasar bagi mereka yang lansia, diuraikan oleh Howard Y.McClusky yang dikutip oleh Robert E. Fillinger, demikian: "Coping need (how do we cope with the loss of job, friends, spouse, money, influence?); expressive needs (how do we help people share themselves, their gifts and resources, with others?); contributive needs (how do we help individuals give and feel needed?); influence needs (everyone needs to feel that she or he is making some impact on society); need for transcendence (how do we help persons find meaning in life and death?)"(Filinger, 1993). Gereja melakukan tugas pendidikan Kristen bagi lansia sebagai sarana pembelajaran yang dapat menolong mereka untuk memahami setiap kebutuhannya. Gereja mengusahakan pemenuhannya, sebagaimana yang diharapkan.

Kepentingan pelaksanaannya didasarkan pada pertimbangan bahwa lansia diibaratkan dengan 'barang yang pecah - dibuang' yakni mereka yang berusia lanjut menghadapi pengasingan, kesepian, dan kehilangan diri. Kondisi sedemikian membuat mereka merasa diri bahwa belajar memberi arti sebagai penyiksaan hidup, dan memperoleh pendidikan Kristen bukanlah suatu hal yang diharapkan. Beberapa alasan umum terkait dengan hal ini, adalah sebagai berikut: pertama, aspek kognitif, lansia kurang atau bahkan tidak mampu untuk mengingat hal-hal baru yang diberikan kepada mereka. Segala sesuatu cenderung mereka lakukan berdasarkan pengalaman. Kedua, aspek fisik, masa penuaan menjadi masalah utama terhadap kondisi kesehatan mereka, mulai dari penglihatan, pendengaran, perasa, dan sebagainya. Ketiga, aspek psikologis, mereka gampang tersinggung terhadap suatu persoalan apapun, khususnya masalah berkenaan dengan dirinya sendiri, seperti: anak atau menantu dan cucunya 'jarang' untuk berkomunikasi; atau perasaan kurang dihargai apabila seseorang dengan usia lebih muda daripadanya 'tidak peduli' terhadap usul ataupun saran, dan sebagainya.

Pemahaman terhadap belajar sebagai perubahan, membutuhkan energi, ruang dan waktu; serta melibatkan keseluruhan pribadi yang meliputi: pikiran, perasaan, kemauan, roh, dan tubuh, yang mencakup aspek internal dan eksternal. Hal ini, tentu menunjukkan suatu pemahaman bahwa belajar merupakan kegiatan yang memengaruhi seluruh aspek kehidupan dan terjadi sepanjang hidup manusia. Tujuan belajar adalah menghasilkan perubahan-perubahan pengetahuan, pemahaman, keterampilan dan nilai-nilai. Perubahan-perubahan tersebut bersifat relatif, konstan, dan berbekas. 
Sementara itu, pandangan Levinson yang dikutip oleh Penney Upton, dalam bukunya Psikologi Perkembangan, mengemukakan bahwa orang dewasa menjalani suatu proses berulang untuk membangun suatu struktur kehidupan dan menilai serta mengubahnya dalam periode-periode transisi. Usia 60 tahun ke atas merupakan masa untuk membangun struktur baru dalam menjalani pensiun dan penuaan (Upton, 2012).

Gereja memahami dan menghayati tentang konsepsi belajar pendidikan Kristen bagi lansia adalah suatu panggilan mulia untuk mempersiapkan dan melatih mereka menjalani masa pensiun dan penuaan dengan ucapan syukur. Karena konteks pendidikan Kristen adalah umat Allah yang tidak dibatasi oleh usia, dan setiap umat Allah saling terkait bagaikan hubungan antara satu anggota tubuh dengan anggota tubuh yang lain (sebagaimana dijelaskan Paulus dalam 1 Kor.12). Dalam hal ini, Henry J.M. Nouwen dan Walter J. Gaffrey mengungkapkan "....memberi perhatian kepada lansia merupakan jalan masuk ke dalam diri sendiri untuk membantu mereka menemukan kebebasan dalam usia senja" (Nouwen \& Gaffney, 2001). Dengan kata lain, belajar yang paling bermakna tentang arti hidup dan perjuangan bertahan terhadap kehidupan itu sendiri adalah mendengarkan pengalaman mereka yang lansia. Lansia membutuhkan pembelajaran yang bersifat life center approach. Karena mereka membutuhkan bimbingan dalam hal kebijaksanaan hidup, diri dan hidup berpengharapan.

Konsepsi belajar pendidikan Kristen bagi lansia merupakan peneguhan iman untuk mengarahkan segala pengharapan dan kasih mereka kepada Yesus Kristus. Gereja memahaminya sebagai konsep dasar terhadap pelaksanaan pembelajaran pendidikan Kristen bagi lansia, karena Yesus Kristus menebus dan mendidik orang percaya untuk hidup sebagai milik-Nya. Sejalan dengan konsepsi inilah, strategi sebagai hal penting untuk direncanakan dan dipedomani oleh gereja dalam upaya mempraktikkan pendidikan Kristen bagi lansia di gereja.

\section{Strategi PAK Lansia di dalam dan sekitar Gereja}

Pada dasarnya, gereja membutuhkan suatu strategi pendidikan Kristen bagi lansia demi tercapainya tujuan pendidikan sebagaimana tertuang dalam Ef.4:11-16. Gereja memiliki kedudukan dan peran yang sangat hakiki dalam mewujudkan mandat Allah yakni "menjadikan semua bangsa murid-Nya" (Mat.28:19-20). Sejalan dengan hal tersebut, Allah sendiri telah menganugerahkan pendidik kepada gereja untuk melakukan tugas pendidikan Kristen sebagai pembangunan tubuh atau jemaat Kristus menuju kedewasaan iman di dalam Kristus. 
Mengutip penjelasan B.S.Sidjabat, dalam bukunya Strategi Pendidikan Kristen: Suatu Tinjauan Teologis-Filosofis, menyatakan tentang kedewasaan dalam Kristus tersebut, adalah: pertama, sebagai pertumbuhan atau proses perubahan hidup (life transformation) oleh kuasa Roh Allah dan pengajaran firman-Nya (bnd. 2 Kor.3:17-18) (Sidjabat, 2000). Kedua, kedewasaan itu meliputi aspek kognitif atau pengenalan, pengertian, pemahaman akan Yesus Kristus, dalam artian secara pribadi (bnd. Ef.1:314; 2:1-10). Ketiga, kedewasaan itu harus terefleksi di dalam komunikasi dan hubungan antar sesama dalam jemaat dan di luarnya, demi terwujudnya pemeliharaan kesatuan Roh (bnd. Ef.4:1-4). Keempat, kedewasaan yang tertuang dalam kegiatan ibadah, doa, dalam rangka memenangkan perlawanan terhadap musuh-musuh rohani (spiritual warfare; bnd.Ef.6:10-11).

Uraian kedewasaan yang penulis kutip di atas menjelaskan, bahwa lansia adalah pengkategorian berdasarkan usia, sehingga mereka digolongkan pada dewasa akhir. Namun, kedewasaan secara usia dapat membimbing lansia memahami kedewasaan dalam Kristus, apabila gereja terbuka melalui pengalaman hidup mereka. Gereja menjadi wadah belajar untuk saling mendewasakan melalui kisah hidup mereka.

Selanjutnya, pernyataan Judowibowo Poerwowidagdo, menuliskan bahwa tujuan PAK adalah untuk membantu peserta didik (warga jemaat: anak-anak dan dewasa) mengembangkan iman dan pengetahuannya tentang Firman Tuhan Allah seperti yang termaktub dalam Alkitab Perjanjian Lama dan Perjanjian Baru, serta pengetahuan dan pengalamannya dalam kehidupan Gereja sebagai tubuh Kristus, dan mengamalkan iman dan pengetahuannya itu dalam kehidupan mereka sehari-hari baik di dalam rumah-tangga, di sekolah, di tempat bekerja dan di tengah masyarakat pada umumnya, sehingga dengan demikian: mereka dapat mengaktualisasikan diri sesuai dengan maksud dan kehendak Tuhan Allah dalam penciptaan (Poerwowidagdo, 2002). Dalam mewujudkannya, penulis mengungkapkan bahwa pendidikan Kristen harus meliputi 3 hal pokok, yaitu: Alkitab, Gereja dan Dunia.

Kemudian, Robert R. Boehlke, seorang tokoh PAK yang memperkenalkan teori pembelajarannya, yakni: Creation Engagement, mengemukakan ada empat pokok pembelajaran pendidikan Kristen yang perlu diperhatikan oleh gereja, adalah sebagai berikut: pertama, respons-respons adalah tindakan yang sesuai dalam perjumpaan pembelajar dengan bidang-bidang relasi di bawah kuasa kreatif Allah (BPK Gunung Mulia, 2010). Creation engagement memandang respons-respons lebih daripada sekadar tindakan berulang dalam kaitan dengan peristiwa, situasi, benda dan pribadi. 
Pembelajaran yang paling dasariah adalah respons pada penyataan Allah. Karena Allah-lah yang menangkap pembelajar dan memberinya kemampuan memandang lebih luas dampak penyataan yang diterima. Respons yang dimaksud meliputi gerakan psikomotoris, psikologia, maupun intelektual, dan spiritual.

Kedua, pembelajar adalah manusia aktif, cerdas, bertanggung jawab, namun berdosa, yang harus dipahami melalui pengamatan, persepsi diri dan kualitas relasinya dan penyataan. Dalam creation engagement, pembelajar boleh memakai refleksi diri sebagai indikator tentang persepsi, aspirasi, emosi dan kebutuhannya sendiri. IImu dan relasi merupakan sumber pengetahuan. Pembelajar mempelajari bahwa dirinya siap secara fisik, psikologis, intelektual dan spiritual untuk terlibat atau dilibatkan dalam bidang-bidang relasinya.

Ketiga, konteks pembelajaran adalah gereja (komunitas perjanjian, Tubuh Kristus, persekutuan Roh Kudus) yang melaluinya pembelajar menemukan bidangbidang relasi pribadi dan non-pribadi. Konteks pembelajaran dalam Creation Engagement digambarkan dalam skema empat lingkaran konsentris dari empat unsur yang saling terkait, yakni: diri pembelajar, relasi pembelajar, gereja, dan Allah.

Keempat, dinamika pembelajaran berjalan ketika pembelajar termotivasi secara eksistensial untuk terlibat dan menstrukturkan ulang bidang-bidang relasinya, juga ketika proses-proses ini digunakan oleh Roh Kudus untuk memunculkan perjumpaan dan respons kepada Yesus Kristus. Motivasi dapat dijelaskan sebagai kebutuhan. Orang termotivasi untuk memenuhi kebutuhannya. Dalam creation engagement, motivasi mengandung gagasan memperkaya kehidupan manusia selaku subjek. Pembelajar melalui Roh Kudus menyadari bahwa pendidikan Kristen membicarakan isu-isu yang sangat bermakna seperti ketegangan kritis ketika kelahiran, remaja, pernikahan, pemilihan karir, penyakit, kematian dan tantangan-tantangan lainnya. Motivasi dapat menolong pembelajar untuk mengembangkan imannya.

Dalam hal ini, strategi pembelajaran pendidikan Kristen bagi lansia yang dilakukan oleh gereja adalah membimbing mereka untuk mengenal Tuhan dan penyataan-Nya secara pribadi (owned faith). Pengenalan akan Tuhan secara pribadi akan mampu mengarahkan keberimanan lansia untuk menghadapi masa tua secara kreatif dan bijaksana serta peka terhadap dinamika kehidupan di dunia ini. Strategi pendidikan Kristen bagi lansia diperlukan untuk mendukung pencapaian ini.

Strategi pendidikan Kristen bagi lansia mengandung arti bahwa pendidik PAK perlu merencanakan kegiatan mengajar sebelum ia melaksanakan tugasnya bersama dengan peserta didik. Ketika pendidik merencanakan strategi pembelajaran, ia pun 
harus mempertimbangkan tujuan, sifat dari bahan pengajaran, peserta didik yang belajar, fasilitas, ruang, dan waktu belajar. B.S. Sidjabat mengutip penjelasan Oemar Hamalik yang memperkenalkan empat jenis strategi pembelajaran untuk diketahui oleh pendidik, yakni (Sidjabat, 2000):

1.Pembelajaran penerimaan (reception learning)... guru (pendidik) berperan aktif menyajikan informasi kepada anak (peserta) didik... setelah itu, anak (peserta) didik diberi kesempatan untuk memikirkan penerapan konsep yang dipelajarinya.

2.Pembelajaran penemuan (discovery learning)... guru (pendidik) memperhadapkan realitas, kasus, atau masalah kepada peserta didik... peserta didik menemukan dan mengemukakan ide, konsep, dan gagasan yang dapat dibawa ke dalam kajian yang lebih luas.

3.Pembelajaran penguasaan (mastery learning)... guru (pendidik) menuntun murid (peserta didik) untuk menguasai sebuah tahapan belajar sebelum beranjak ke tahapan berikutnya...

4.Pembelajaran terpadu (unit learning)... guru (pendidik) menuntun peserta didik untuk memahami sebuah unit kasus atau peristiwa dari berbagai aspek atau sudut pandang sehingga mereka memiliki pemahaman yang menyeluruh dan integratif.

Keempat jenis tersebut masih bisa dikembangkan pendidik dengan berorientasi kepada peserta didik aktif, sehingga pembelajaran yang dilakukan lebih bersemangat. Lansia memperoleh pendidikan Kristen di gereja, bukanlah hanya untuk meningkatkan pengetahuan mereka tentang isi (doktrin) Alkitab, tetapi juga memahami isi Alkitab dengan berbagai bentuk literaturnya yang dipahami secara kritis. Hal ini bertujuan agar mereka dapat membangun pemahaman tentang pokok-pokok iman Kristen dalam menghadapi berbagai masalah kehidupan. Sebagaimana David Moberg yang dikutip oleh Kenneth O. Gangel mencatat "spiritual nurture is the number one task of the church in its work with the aging. But other ministries, rightly conducted, will aid in performing that task and increase the effectiveness of the church"(Gangel, 1998). Hal ini menegaskan bahwa strategi pendidikan Kristen bagi lansia merupakan tugas pendidik dalam memberikan pengasuhan rohani (hati) sebagai perwujudan terhadap salah satu tugas gereja. Dengan kata lain, pendidikan Kristen bagi lansia di gereja merupakan proses belajar pengasuhan rohani (hati atau spiritual) yang berusaha menghindari diri dari sikap menggurui, merasa diri 'paling tahu', pemutus 
pembicaraan, berdebat, dan sikap diskriminatif. Karena strategi pendidikan Kristen bagi lansia terlaksana bila pendidik tetap memandang tinggi atau tidak menganggap sepele mereka yang lanjut usia. Sebagaimana Andar Ismail yang dikutip oleh B.S. Sidjabat menyatakan, demikian:

Orang lanjut usia bukan anak kecil yang bisa dijadikan bahan tertawaan.

Memang sekarang kita berganti peran menjadi pengayom dan pengasuh mereka, namun kedudukan mereka tidak berubah, kita bukan orangtua mereka, merekalah orangtua kita. Memang mereka sudah banyak lupa, namun mereka tahu lebih banyak daripada kita dan sebetulnya mereka lebih bijak daripada kita (Sidjabat, 2014).

Demikianlah gereja memandang lansia sebagai manusia seutuhnya, mencakup pribadi dan kelompok. B.S. Sidjabat yang mengutip pernyataan Lawrence O. Richards menguraikan tentang konsep sosialisasi yang diasumsikan sebagai berikut: pertama, manusia adalah pribadi-pribadi aktif, dan sebab itu ingin diaktifkan; kedua, manusia senantiasa dalam struktur keterikatan atau kebergantungan satu sama lain (saling membutuhkan); ketiga, manusia membutuhkan lingkungan struktural (konteks sosial) dalam pertumbuhan dan perkembangannya; keempat, manusia harus menyatakan pertumbuhan itu dalam realitas relasional (Sidjabat, 2000). Inilah acuan penting yang menjadi prinsip gereja untuk mempraktikkan pendidikan Kristen bagi lansia.

\section{Prinsip dan Praktik Pendidikan Kristen Bagi Lansia}

Prinsip pendidikan Kristen yang dilakukan oleh seorang pendidik, umumnya didasarkan pada konteks pembelajar. Karena prinsip, sebagaimana penulis kutip dari Kamus Besar Bahasa Indonesia, merupakan hal yang fundamental dari sebuah perkembangan ataupun perubahan, dan akumulasi dari pengalaman ataupun pemaknaan oleh sebuah objek atau subjek tertentu. Sejalan dengan pengertian ini, prinsip pendidikan Kristen bagi lansia adalah berpusat pada perkembangan atau perubahan lansia dalam memaknai perjalanan kehidupannya.

Dalam hal ini, penulis mengutip penjelasan B.S. Sidjabat yang menguraikan beberapa prinsip pendidikan Kristen yang dapat dijadikan acuan penting dalam mendidik lansia, adalah sebagai berikut: prinsip pertama, orang dewasa lanjut tetap membutuhkan pembinaan iman (rohani), sebagaimana dituliskan dalam Titus 2:1-5, “...laki-laki yang tua hendaklah hidup sederhana, terhormat, bijaksana, sehat dalam iman, dalam kasih dan dalam ketekunan...perempuan-perempuan tua, hendaklah 
mereka hidup sebagai orang-orang yang beribadah, jangan memfitnah, jangan menjadi hamba anggur, tetapi cakap mengajarkan hal-hal baik..." Prinsip kedua, bahan-bahan pengajaran harus diupayakan relevan dengan kebutuhan orang dewasa usia lanjut, antara lain: pengenalan akan Tuhan lebih bersifat pribadi (owned faith), tanggung jawab terhadap diri sendiri dalam arti menghadapi masa tua secara kreatif mencakup konsep dan penerimaan diri serta pola hidup, dan perilaku seksual, tanggung jawab terhadap keluarga, anak-anak dan cucu...menjadi penasehat yang bijaksana, tanggung jawab terhadap gereja (warga jemaat) dan masyarakat, dasar hidup bahagia dan sejahtera. Prinsip ketiga, pendekatan dalam pelayanan... perlu kita kembangkan dengan memperhatikan perubahan mental mereka. Prinsip keempat, membina orang dewasa lanjut...mencakup pemenuhan layanan bagi kebutuhan fisik dan psikologis serta kesehatan mereka (Sidjabat, 2006).

Sejalan dengan uraian di atas, penulis mengutip Robert W. Pazmino, menuliskan ada 5 model tugas pendidikan Kristen di gereja, yaitu: "proclamation, community, service, advocacy, and worship - are essential to the life and mission of the Christian church, and they serve to distinguish Christian education from general education" (Pazmino, 1992). Kelima model tugas ini menjadi prinsip penting dalam mempraktikkan pendidikan Kristen bagi lansia di gereja. Tujuannya adalah untuk membimbing mereka untuk mengenal Tuhan dan penyataan-Nya secara pribadi (owned faith). Pengenalan akan Tuhan secara pribadi mampu mengarahkan keberimanan lansia untuk menghadapi masa tua secara kreatif dan bijaksana serta peka terhadap dinamika kehidupan di dunia ini.

Kelima model tugas tersebut menempatkan kepentingan pendidik yang terdidik dalam mendidik lansia dengan meneladani Kristus yang didasarkan pada suatu prinsip tertentu. J.M. Price, mencatat ada tujuh prinsip dasar pengajaran-Nya, yakni (Price, 1998): pertama, memandang jauh ke depan (Yesus melihat kemungkinankemungkinan peserta didik-Nya pada masa depan, yang tidak hanya berbicara tentang pembentukan kecapakan mereka pada masa sekarang, tetapi mendidik dan membimbing peserta didiknya untuk mampu menemukan kemampuan-kemampuan tersembunyi yang mereka miliki, yang bermanfaat bagi pertumbuhan mereka ke arah lebih dewasa/matang dalam segala hal). Ini tampak jelas dalam hubungan Yesus dengan peserta didik-Nya yang memperlihatkan pengenalan-Nya akan karakterkarakter peserta didik, cukup baik.

Kedua, Yesus menekankan hubungan perseorangan. Yesus lebih banyak menghabiskan waktu bersama dengan pribadi-pribadi (seperti: percakapan-Nya 
dengan Nikodemus, percakapan-Nya dengan perempuan Samaria, percakapan-Nya dengan Zakheus, undangan makan dengan salah seorang ahli taurat di rumahnya, $\mathrm{dsb}$ ), atau kelompok kecil - walaupun kadangkala la bersama dengan orang banyak. Ketiga, Yesus mengajar secara wajar dan tidak formil. Dia selalu memulainya berdasar pada kepentingan dan keperluan peserta didik-Nya. Yesus tidak memulai pengajaranNya dengan kepercayaan-kepercayaan yang telah dirumuskan lebih dahulu, tidak dengan suatu pokok tertentu, tidak dengan tradisi, bahkan tidak dengan Kitab Suci, Yesus memulainya dengan pengalaman-pengalaman hidup orang-orang mendengarNya, atau pengalaman hidup para peserta didik-Nya (lih. Luk.4:16-30). Yesus memulai pengajaran dengan perhatian dan keperluan mereka, serta menggunakan bahasa yang mudah dimengerti oleh peserta didik.

Keempat, selama mengajar, Yesus langsung membicarakan hal-hal yang penting saja, yakni masalah-masalah yang berhubungan dengan kehidupan susila dan agama, masalah-masalah hidup yang timbul dari naluri-naluri dasar, seperti: naluri menyelamatkan diri, naluri berbiak, naluri proyektif, dan naluri sosial. Kelima, Pengajaran Tuhan Yesus lebih terarah pada pengolahan hati nurani daripada pengembangan akal budi atau kognitif semata - tujuannya: agar peserta didik memiliki rasa tanggung jawab moral atau kepekaan terhadap hal yang benar dan salah (bnd. Luk. 11:46, Mat. 23:23, Mat. 25:27). Keenam, Yesus juga menarik apa yang terbaik dari diri peserta didik-Nya, seperti: seorang Farisi yang selalu merasa dirinya benar, seorang pemungut cukai yang tamak, seorang wanita yang hina, dsb. Yesus menghidupkan iman mereka dengan cara menolong mereka untuk dapat berubah, karena mereka pasti memiliki sifat baik yang dapat dimunculkan dan dikembangkan.

Ketujuh, Yesus melakukan tugas pengajaran dengan mendorong dan membimbing kegiatan peserta didik-Nya dalam hal ketaatan pada Firman-Nya. Hal ini diumpamakan dengan seorang yang mendirikan rumah di atas pasir dan seorang yang mendirikan rumah di atas batu (lih. Luk. 6:47-48). Pengajaran Yesus adalah pengajaran pendengaran, perasaan, pikiran dan perbuatan.

Prinsip-prinsip sedemikian menjadi landasan gereja untuk mempraktikkan pendidikan Kristen bagi lansia berdasarkan realisasi misi dan rencana Allah (God's ministry) di dunia ini. Artinya, kehadiran lansia penting, sebagai kelompok dewasa lanjut yang menjadi alat Tuhan untuk mengaktualisasikan tugas dan panggilan pelayanan mereka. Pendidik berperan penting dalam membina dan mendidik lansia sebagai jemaat dewasa lanjut. Peranan teladan hidup dan identifikasi melalui pengamatan dan penilaian gaya hidup pendidik yang juga dididik merupakan hal 
terpenting untuk diperhatikan. Dalam hal ini, Harianto GP menjelaskan tiga bentuk kegiatan praktik pendidikan Kristen yaitu ibadah, persekutuan, dan pengajaran. Uraian ketiga bentuk ini, sebagai berikut (Harianto, 2012):

1.Ibadah, yaitu cara berhubungan dengan Allah yang benar.

2.Persekutuan, gereja adalah persekutuan orang-orang beriman yang dosadosa mereka telah ditebus Tuhan.

3.Pengajaran, gereja bertugas mengomunikasikan dan membagikan warisan kebenaran Kristen kepada umat-Nya dan semua orang di dunia. Pengajaran ini dapat diberikan dalam bentuk: (a) Ajaran gereja (instruction), yaitu dengan memberikan informasi tentang fakta-fakta seperti sejarah gereja, doktrin-doktrin Kristen; (b) Pendidikan gereja, yang melibatkan seluruh murid dalam proses belajar; (c) Pembinaan gereja, mirip dengan pendidikan, tetapi hanya lebih mendasar dan tujuannya mengarah pada penyerahan diri.

Pengembangan bentuk kegiatan ini dapat dilakukan oleh seorang pendidik melalui penyesuaian terhadap kebutuhan, minat, persoalan, dan kerohanian atau spiritual lansia. Sejalan dengan hal tersebut, praktik pendidikan Kristen di gereja, penulis kutip dari penjelasan B.S. Sidjabat yang mengutip Vivian R. Mc.Coy, mengusulkan, sebagai berikut (Sidjabat, 2014):

\begin{tabular}{|c|c|c|c|}
\hline Usia & Tugas Kehidupan & $\begin{array}{c}\text { Kegiatan } \\
\text { Pembelajaran }\end{array}$ & $\begin{array}{c}\text { Hasil } \\
\text { Pembelajaran }\end{array}$ \\
\hline \multirow{3}{*}{$\begin{array}{l}65 \text { th. }+ \text { : } \\
\text { Berhenti } \\
\text { dari } \\
\text { aktivitas } \\
\text { rutin }\end{array}$} & $\begin{array}{l}\text { 1.Tidak lagi bekerja } \\
\text { untuk mendapatkan } \\
\text { upah seperti biasanya }\end{array}$ & $\begin{array}{l}\text { 1.Pembinaan } \\
\text { menghadapi } \\
\text { pensiun, } \\
\text { penuaan, dan } \\
\text { volunteer }\end{array}$ & $\begin{array}{l}\text { 1. Hidup menjad } \\
\text { lebih kreatif dan } \\
\text { berguna }\end{array}$ \\
\hline & $\begin{array}{l}\text { 2.Memperhitungkan } \\
\text { kembali keuangan }\end{array}$ & $\begin{array}{l}\text { 2.Latihan dalam } \\
\text { hal keuangan }\end{array}$ & $\begin{array}{l}\text { 2. Mampu } \\
\text { mengatasi } \\
\text { masalah } \\
\text { keuangan (?) }\end{array}$ \\
\hline & $\begin{array}{l}\text { 3.Bergumul dengan } \\
\text { kesehatan fisik }\end{array}$ & $\begin{array}{l}\text { 3.Program } \\
\text { menjaga } \\
\text { kesehatan }\end{array}$ & $\begin{array}{l}\text { 3.Mampu } \\
\text { menjaga } \\
\text { kesehatan }\end{array}$ \\
\hline
\end{tabular}




\begin{tabular}{|c|c|c|}
\hline $\begin{array}{l}\text { 4.Mencari cara baru } \\
\text { untuk memenuhi } \\
\text { kebutuhan }\end{array}$ & $\begin{array}{l}\text { 4.Kegiatan } \\
\text { pembinaan } \\
\text { kerohanian }\end{array}$ & $\begin{array}{l}\text { 4.Memaknai } \\
\text { kehidupan } \\
\text { dengan baik dan } \\
\text { benar }\end{array}$ \\
\hline $\begin{array}{l}\text { 5.Mengelola waktu yang } \\
\text { ada }\end{array}$ & $\begin{array}{l}\text { 5.Pembinaan } \\
\text { tentang } \\
\text { menghadapi } \\
\text { kesendirian dan } \\
\text { kesepian }\end{array}$ & $\begin{array}{l}\text { 5.Mampu hidup } \\
\text { tanpa pasangan }\end{array}$ \\
\hline $\begin{array}{l}\text { 6.Menyesuaikan diri } \\
\text { dengan pernikahan }\end{array}$ & $\begin{array}{l}\text { 6.Pembahasan } \\
\text { tentang kematian }\end{array}$ & $\begin{array}{l}\text { 6.Menerima } \\
\text { kematian yang } \\
\text { akan datang, } \\
\text { membantu } \\
\text { mereka yang } \\
\text { menuju } \\
\text { kematian, dan } \\
\text { mampu } \\
\text { mengatasi } \\
\text { dukacita }\end{array}$ \\
\hline $\begin{array}{l}\text { 7.Menghadapi hidup } \\
\text { tanpa pasangan }\end{array}$ & $\begin{array}{l}\text { 7.Pemecahan } \\
\text { masalah kreatif }\end{array}$ & $\begin{array}{l}\text { 7.Berhasil } \\
\text { menghadapi } \\
\text { masalah }\end{array}$ \\
\hline $\begin{array}{l}\text { 8.Bersiap menghadapi } \\
\text { kematian }\end{array}$ & 8.Mengelola Stres & $\begin{array}{l}\text { 8.Berhasil } \\
\text { mengatasi stress } \\
\text { kehidupan. }\end{array}$ \\
\hline $\begin{array}{l}\text { 9.Menghadapi masalah } \\
\text { yang muncul }\end{array}$ & & \\
\hline $\begin{array}{l}\text { 10.Mengelola stress dan } \\
\text { perubahan hidup }\end{array}$ & & \\
\hline
\end{tabular}

Prinsip dan praktik pendidikan Kristen bagi lansia ini, tentu berkaitan dengan pemanfaatan pendekatan yang efektif. Karena lansia membutuhkan dukungan sosial yang dapat menolongnya bertumbuh, dengan melakukan kegiatan yang berguna. Dukungan-dukungan tersebut adalah dari anggota keluarga (seperti: pasangan hidup, anak - menantu, dan cucu), teman dekat yang akrab, teman sekelompok, dan 
sebagainya. Jika lansia memiliki suatu komunitas yang saling membangun dalam melakukan kegiatan bersama, saling bercerita, membagi minat dan perhatian, serta berekreasi bersama, maka ia akan merasa bahwa masa tua itu bukanlah suatu 'bencana'. la dapat menjalani kehidupannya dengan melakukan beragam kegiatan yang ia sukai. Demikianlah gereja memerankan dirinya dengan melibatkan setiap kategorial pelayanan dalam tugas pendidikan Kristen.

\section{KESIMPULAN}

Kehadiran para lansia di tengah-tengah gereja merupakan rencana dan kehendak Allah untuk menghadirkan misi penyelamatan-Nya yang tidak hanya fokus kepada anak-anak hingga dewasa menengah. Sekalipun keberadaan mereka, mungkin, 'membosankan' tetapi pendidikan Kristen tetap perlu untuk diadakan (bila gereja belum atau tidak peduli terhadap pengadaan pendidikan dan/atau pembinaannya) atau dikembangkan (bila gereja telah membuat program pendidikan Kristen bagi lansia). Karena lansia juga membutuhkan bimbingan dari gereja untuk mengarahkan diri dan hidup berpengharapan kepada Kristus.

Mengutip pernyataan bijak Mary Elizabeth Mullino Moore, demikian: "Teaching from the heart is similarly connected to the wholeness of the body. Teaching from the heart is teaching from a source that needs the rest of the body to exist' (Moore, 1995). Kedudukan dan peranan gereja terhadap pelaksanaan pendidikan Kristen bagi lansia hanya terwujud sesuai dengan kehendak dan rencana Tuhan, apabila gereja mengupayakan pembelajaran dari dalam hati. Hal ini didasarkan pada kerinduan para lansia agar mereka dieksistensikan sebagai salah satu kategori umur yang patut dibimbing hidup dalam kebijaksanaan dan teguh berpengharapan kepada-Nya. Sejalan dengan strategi, prinsip dan praktik pendidikan Kristen yang telah diuraikan, setiap pendidik bagi lansia perlu hadir, dan berada di tengah-tengah mereka untuk merasakan, menghayati, menggumuli dan membimbing dalam menemukan hikmat Allah terhadap persoalan mereka. Hal ini tidak mudah, karena setiap pendidik perlu menempatkan dirinya sebagai yang mendidik sekaligus dididik melalui beragam pengalaman hidup mereka. Pendidik belajar dari lansia, dan lansia dididik secara kerohanian. Demikianlah mereka mampu memaknai kehidupan masa lansia sebagai kehendak Allah. 


\section{DAFTAR PUSTAKA}

Bandung, S. (n.d.). Refleksi: Pelayanan Pendidikan Kristen di Gereja.

BPK Gunung Mulia. (2010). Memperlengkapi Bagi Pelayanan dan Pertumbuhan:

Kumpulan Karangan Pendidikan Kristiani. BPK Gunung Mulia.

Filinger, R. E. (1993). Teaching Older Adults. In K. O. Gangel \& J. C. Wilhoit (Eds.),

The Christian Educator's: Handbook on Teaching. Victor Books.

Gangel, K. O. (1998). Teaching Adults in the Church. In K. O. Gangel \& H. G.

Hendricks (Eds.), The Christian Educator's: Handbook on Adult Education.

Baker Book.

GKPI. (2019). Peresmian Rumah Lansia Sejahtera GKPI 10 Mei 2019.

http://www.gkpi.or.id

Harianto. (2012). Pendidikan Agama Kristen dalam Alkitab dan Dunia Pendidikan

Masa Kini: Pembahasan Lengkap tentang Dasar, Implementasi, dan Penerapan

Pendidikan Agama Kristen dalam Perjanjian Lama, Perjanjian Baru, dan

Kehidupan saat ini. Andi.

Hurlock, E. (2004). Psikologi Perkembangan: Suatu Pendekatan Sepanjang Rentang Kehidupan (Istiwidayanti \& Soedjarwo (eds.)). Erlangga.

Moore, M. E. M. (1995). Teaching from the Heart: Theology and Educational Method.

Fortress Press.

Nazir, M. (2003). Metode Penelitian. Ghalia Indonesia.

Nouwen, H. J. M., \& Gaffney, W. J. (2001). Meniti Roda Kehidupan: Tambah Usia

Menuju Kepenuhan Hidup. Kanisius.

Pardomuan, J. (2017, September 9). Mendalami Kepemimpinan Musa. Analisadaily.

Pazmino, R. W. (1992). Principles and Practices of Christian Education. Baker Book.

Poerwowidagdo, J. (2002). Pendidikan Hak Asasi Manusia dalam Pendidikan Agama

Kristen. In A. Ismail (Ed.), Ajarlah Mereka Melakukan. BPK Gunung Mulia.

Price, J. M. (1998). Yesus Guru Agung. LLB.

Santoso, H., \& Ismail, A. (2016). Memahami Krisis Lanjut Usia. BPK Gunung Mulia.

Sidjabat, B. S. (2000). Strategi Pendidikan Kristen: Suatu Tinjauan Teologis -

Filosofis. Andi.

Sidjabat, B. S. (2006). Pendewasaan Manusia Dewasa: Strategi Pembinaan Orang

Dewasa di dalam dan melalui Jemaat. Institut Alkitab Tiranus.

Sidjabat, B. S. (2014). Pendewasaan Manusia Dewasa: Pedoman Pembinaan Warga Jemaat Dewasa dan Lanjut Usia. Kalam Hidup.

UKDW. (n.d.). Gereja dan Kaum Lansia. Retrieved February 2, 2022, from 
https://katalog.ukdw.ac.id/52140005_bab1_bagianpendahuluan

Upton, P. (2012). Psikologi Perkembangan (N. F. Widuri (ed.)). Erlangga.

Yasmin, P. (2021, November 8). Pensiun PNS Umur Berapa? Ini Batas Usia untuk para Guru. DetikEdu. 